\title{
VISION OF OWN PARENTING \\ IN SINGLES AND PEOPLE \\ INVOLVED IN A ROMANTIC RELATIONSHIP
}

\begin{abstract}
Although it is generally assumed that experiences related to being in a romantic relationship are important for forming attitudes toward being a parent, yet there has been no reliable empirical evidence for that. Two empirical studies have been conducted to examine relations between status and length of romantic relationship and vision of own parenting (VOP). The first of them was conducted on 178 teenagers and young adults aged from 18 to 32 with the use of a survey related to predictions about being a parent in the future. In the second study, conducted on 413 young people aged from 17 to 29, the Vision of Own Parenting Questionnaire (VOPQ) was used. The structure and the content of the vision of own parenting of singles and people involved in a romantic relationship were compared. Relations between time spent in this relationship and extension of the VOP were also subject to examination. The results of both studies revealed that people involved in a romantic relationship value parenthood higher than singles, have a more extended vision of their own parenting, and have a greater desire to participate in different forms of preparation for being a parent. They also predicted more positive changes in the relationship with a life partner after childbirth, and had fewer doubts about being a parent in the future. These findings support the common thought and some theoretical concepts that being in a romantic relationship is related to forming attitudes toward being a parent in the future.
\end{abstract}

Keywords: vision of own parenting; singles; couples; romantic relationship.

Correspondence concerning this article should be addressed to KAMIL JANOwICZ, Faculty of Psychology and Cognitive Science, Adam Mickiewicz University, ul. A. Szamarzewskiego 89/AB, 60-568 Poznań, Poland; email: kamil.janowicz@amu.edu.pl; ORCID: https://orcid.org/0000-0002$6193-5331$

The research and publication of this article have been financially supported by the Faculty of Psychology and Cognitive Science, Adam Mickiewicz University. 


\section{INTRODUCTION}

Parenthood is one of the most common life experiences among men and women. Regardless of changes in contemporary societies, it is still highly valued by young people (Dziwańska, 2007; Twenge et al., 2012). A substantial difference in the way of fulfilling the parental role may be observed among people, even in the same culture or social group. Similarly, the ways to become a parent vary as well. Taken together, it encourages researchers to investigate factors related to a more successful adaptation to parenthood and being a better and more satisfied parent.

An engagement in any social role is usually preceded by the process of forming images about oneself in this role. Earlier experiences, patterns of social roles, intergenerational transmission, knowledge gained during the process of socialization, personal values and many other factors may influence the content and the structure of these images. One of the factors widely recognized in the literature (e.g., Crissey, 2005; Joyner \& Udryn, 2000; Schulman \& Seiffge-Krenke, 2001) as important in the process of forming images about being a parent in the future are experiences gained in romantic relationships. However, this belief has not been properly supported by data yet. Although this subject is strongly related to daily life, far too little attention has been paid to verify the role of experiences from being in a romantic relationship in the process of adaptation to parenthood and forming attitudes toward it.

This paper will present the results of two studies, one qualitative and the other quantitative, conducted to verify the research hypotheses about the relation between the status of a romantic relationship and the content and the structure of the vision of own parenting (VOP). Predictions about being a parent in the future were compared between singles and people in a romantic relationship. Also, the relation between the time spent in a romantic relationship and the extension of the vision of own parenting was examined.

\section{ROMANTIC RELATIONSHIPS IN YOUNG PEOPLE}

Engagement in romantic relationships is a common experience in adolescence and early adulthood (Izdebski, 2012). Being in a romantic relationship may be related to sexual activity among partners. Data from several studies investigating sexual activity in Polish young people carried out in recent years (Beisert, 2012; Izdebski, 2012) revealed that a major part of them had had 
a sexual initiation. Having sex with a partner may lead to a pregnancy, which must be considered by the partners. Thinking about that may stimulate reflection on parenthood planning. However, most young people prefer to postpone having a baby. Interestingly, for young men, an unwanted pregnancy has been the strongest concern (stronger even than contracting a sexually transmitted disease) related to having unprotected sex (Smith et al., 2011). They perceived having a baby as something permanently and widely limiting their life.

Although romantic relationships may have various forms and may play a diverse social and psychological function for coupled people, experiences gained in them are assumed to be important for development of teenagers and young adults (Bakiera, 2009). A better state of health (Goodwin et al., 1990; Murphy et al., 1997), higher life satisfaction, and higher level of well-being (Braithwaite et al., 2010; Janicka 2012) are reported as positive outcomes of being engaged in a romantic relationship. There is also copious literature, mainly theoretical papers about the role of being in a romantic relationship in young people's development. A few of the most important thoughts of prominent developmental psychologists on that subject will be presented in this part of the paper.

First, Haley (1973, as cited in Ostoja-Zawadzka, 1999) mentioned dating and engagement as the first phase of the cycle of family life, preceding relationship formalization and having children. This concept indirectly emphasizes the impact of interactions between partners in the early period of their relationship on its future shape and their prospective family life. Second, Havighurst (1981, pp. 4590), pointed out that developmental tasks related to fulfilling family roles (selecting a mate, learning to live with a marriage partner, starting a family, and rearing children) follow on those related to developing intimate relationship (achieving new and more mature relations with age-mates of both sexes, and preparing for marriage and family life). Taking these thoughts into consideration, it may be possible to state that it is impossible to undertake tasks related to parenthood without having a close and stable intimate relationship with a partner. Similarly, Erikson $(1997,2004)$ mentioned that these aspects of life follow one after another, pointing out that gaining intimacy in a close relationship precedes becoming a generative person. Finally, Levinson's theory ought to be mentioned here. As one of the crucial developmental tasks of the Novice Phase (period between 17 and 33 years old) he mentioned forming and living out the Dream, which is "a vague sense of self-in-adult-world. It has quality of a vision, an imagined possibility that generates excitement and vitality" (Levinson, 1988, p. 91). The process of forming the Dream may be facilitated (or sabotaged!) by a close person, e.g., a spouse. He wrote (1988, p. 108) that people at the Novice Phase "seek 
a person who will appreciate his/her emerging aspirations and want to share his/her planned life with them." From this perspective, being engaged in a romantic relationship is not only a developmental task (Havighurst, 1981) but also a need for young people. In view of all concepts listed so far, one may suppose that being involved in a romantic relationship may influence future family life and forming predictions about it.

\section{VISION OF OWN PARENTING}

In the present research, the vision of own parenthood (VOP) is understood as "the person's idea of themselves as a parent in the future and his/her path toward becoming a parent" (Janowicz, 2017, p. 74). It refers to a predicted state of reality, not to a longed-for state. It is important to emphasize that the vision of own parenting is not a type of life goal. It is rather a Levinsonian Dream in relation to parenting (Janowicz \& Bakiera, 2018). It can be described with respect to its content (to what it is built from) and its structure (how it is built). On the basis of a literature review, five aspects of the VOP were isolated: planning, preparation for parenting, taking part in a child's life, relation between parenting and other areas of life, and parenthood valuing. Developing the vision of own parenting may be understood as part of the preparation for entering into and afterwards fulfilling a parental role.

Current knowledge about young people's vision of their future parenting is largely based upon qualitative studies conducted by psychologists and sociologists (e.g., Gajtkowska, 2016; Jacques \& Radtke, 2012; Maher et al., 2004; Majdzińska \& Śmigielski, 2010; Majorczyk, 2014; Marsiglio et al., 2000; Smith et al., 2011; Thompson et al., 2013). Another group of studies focused on family planning and reproduction. They were performed by Scandinavian researchers (Lampic et al., 2005; Skoog Svanberg et al., 2006; Virtala et al., 2001) on hundreds of people with the use of online surveys. Together, these studies suggest that although becoming a parent in the future is important for young people, they still have many doubts concerning it. On the other hand, the results of the aforementioned studies have demonstrated that there is a growing number of people who do not want to become parents at all. This phenomenon is referred to as "voluntary childlessness" and it has been widely discussed in the literature for several decades (e.g., Bloom \& Pebley, 1982; Tanturri \& Mencarini, 2008). Being a parent in the future is still more important to women than to men. Women also see more important circumstances for making a decision to have children. 
Many people reported experiencing a feeling of unreadiness to become a parent and concerns associated with a potential inability to combine the role of a parent with other duties (e.g., education, work). Graduating, starting a full-time job, being in a stable, intimate relationship and having a sense of one's own emotional maturity were all perceived as necessary conditions for making a decision about having a child (Janowicz, 2018; Janowicz \& Bakiera, 2018; Maher et al., 2004; Marsiglio et al., 2000; Thompson et al., 2013). Most of the interviewees declared their attachment to the traditional patterns of family roles, but there were also individuals who were more eager to implement "new" parenthood models. This clash between the traditional and modern family roles patterns was vividly discussed by the interviewees. Previous studies in this area showed that the part of the vision of own parenting related to preparation and sense of readiness for being a parent is more extended than predictions about fulfilling the parental role itself. There are several studies that provide some empirical evidence on the differentiating role of gender, age, or education level in the vision of own parenting content, but none of them has explored status of an intimate relationship.

\section{RESEARCH QUESTIONS AND HYPOTHESES}

Many authors claim that predictions about being a parent in the future may be related to the experience gained in an intimate relationship, but no empirical data proving this idea have been presented yet. The aforementioned idea is also present in common beliefs. According to some theoretical background presented in the previous part of this paper, this thesis seems to be plausible. Thus, the main research goal of studies presented in this paper is investigating relations between the status of an intimate relationship and the content and structure of the vision of own parenting in young childless people.

In particular, the following hypotheses have been posed:

H1: People involved in a romantic relationship have more extended and optimistic vision of own parenting than singles.

$\mathrm{H} 2$ : People with a cumulatively longer time spent in romantic relationships have more extended and optimistic vision of own parenting than people with a shorter time spent in romantic relationships.

These hypotheses have been verified in two empirical studies conducted with various forms of measuring the vision of own parenting. Study 1 was carried out in a qualitative approach, while Study 2 was performed out in a quantitative approach. 


\section{STUDY 1}

\section{Method}

\section{Participants and Procedure}

The research was carried out in a paper version $(60 \%)$ and online version $(40 \%) .{ }^{1}$ The groups differed in terms of gender $\left(\chi^{2}(1,180)=12.401, p<.001\right.$; there were more women in the group of participants filling on-line version), age $(t(178)=-20.11, p<.001$; mean age was higher in the group of participants filling on-line version) and intimate relationship status $\left(\chi^{2}(1,180)=26.61\right.$, $p<.001$; participants filling on-line version were more frequently engaged in a romantic relationship). ${ }^{2}$ In total, 180 participants aged between 17 and 29 $(M=21.25, S D=2.98)$ were recruited in Study $1 ; 58.0 \%(n=104)$ of them were female. With regard to romantic relationship, $38.9 \%(n=79)$ were single, $40.9 \%$ $(n=83)$ were partnered, but not cohabiting, 5.9\% $(n=12)$ were involved, and $3.3 \%(n=6)$ were married. With respect to declared socioeconomic status (SES), $3.9 \%(n=7)$ declared a bad or a very bad SES, $48.9 \%(n=88)$ declared average SES, and $47.2 \%(n=85)$ declared SES "better than an average." All participants were native citizens of Poland living in a major city (over 400,000 citizens).

\section{Research Method}

In Study 1, a survey related to the vision of own parenting was used. It was developed on the basis of questions posed in previous studies on the VOP, analysis of theoretical and empirical papers about parenthood, and the conceptualization of the VOP, as mentioned above in the paper. The survey used in the study

\footnotetext{
${ }^{1}$ It should be mentioned that the results were slightly different in both groups in the following aspects of the VOP: considering the best age for having the first child, readiness for feeding and changing diapers, and willingness to take part in workshops, consultations and regular group meetings intended to prepare for parenting. Participants from the on-line group achieved higher scores (indicating greater readiness/higher willingness/more frequent presence of reflection on parenthood planning) in relation to the aforementioned aspects of the vision of own parenting. Since the participants from both groups differed in terms of gender, age, and status of an intimate relationship, further analyses (e.g., ANCOVA) revealed that the aforementioned differences in the VOP extension were rather related to those factors than to condition of the study itself. This issue will be discussed in the part describing the study limitations.

${ }^{2}$ This difference is more likely to be related to the age rather than the conditions of the studyyoung adults are more frequently engaged in romantic relationships than teenagers (Beisert, 2012; Izdebski, 2012).
} 
contained: (a) 6 closed-ended questions (e.g., Do you think it is possible to prepare for being a father/mother?-Yes/No); (b) 13 open-ended questions with a few blank lines following each question (e.g., How can you prepare for being a father/mother?); (c) 8 graphic scales with extreme points indicated (e.g., How important is it for you to be a father in the future?-from Completely unimportant to This is the most important thing in my life); d) 5 numeric scales ranging from 1 (I am sure I will not take part) to 5 (I am sure I will take part) referring to the willingness to participate in five kinds of pre-parenting instruction (the scales were preceded by the question: Do you want to take part in the following forms of pre-parenting instruction?).

The data from the open-ended questions were analyzed in both qualitative and quantitative ways. First, after reading all the answers, categories related to each aspect of the vision of own parenting were developed (e.g., financial stability, reading books about parenting and emotional maturity as a way of preparing for parenthood). Second, all the answers were coded in relation to these categories. Third, some rarely presented categories were merged into broader categories (e.g., reading books about parenting and visiting websites about parenting were merged into the category labelled as "Literature and websites about parenting." This final list of categories was discussed with the Authors' Supervisor. After that, all answers were read one more time and coded by means of these categories. It should be mentioned that it was possible to code one answer to more than one category. More detailed information about the manner of analyzing qualitative data was presented in my previous paper reporting findings on the content of the vision of own parenting in teenagers (Janowicz, 2018) and young adults (Janowicz \& Bakiera, 2018).

\section{Results}

The results of Study 1 will be presented in the following manner. First, results supporting and challenging Hypothesis 1 will be presented. Second, results supporting and challenging Hypothesis 2 will be presented. The following analyses were conducted in the study: one-way analyses of variance (ANOVA), and $\chi^{2}$ test for independent samples.

The first hypothesis, assuming that people involved in a romantic relationship have more extended and optimistic VOP than singles, got some support in the data, but only in relation to the aspects of the VOP like planning, preparation and valuing. People involved in a romantic relationship more often mentioned having a family or children in their predictions about their future. Further analy- 
sis showed that this difference was significant only in the group of men $\left(M=95 \%\right.$ vs $\left.M=70 \%, \chi^{2}(1,76)=8.10, p<.01\right)$. Singles less often mentioned a precise predicted number of children at the age of $35(M=36 \%$ vs $M=51 \%$, $\left.\chi^{2}(1,178)=4.05, p<.05\right)$, or thought about how many children they would like to have $\left(M=79 \%\right.$ vs $\left.M=93 \%, \chi^{2}(1,178)=7.59, p<.01\right)$. Considering, in turn, the valuing of being a parent in the future, it was higher (on a 0-100 scale) in the coupled people than in singles $(M=73[S D=23.63]$ vs $M=62[S D=26.31]$, $F(1,178)=8.02, p<.01, d=.440$, on a $0-100$ scale $)$. They also were more eager to take part in an academic lecture $(M=3.25[S D=1.28]$ vs $M=2.85$ $[S D=1.30], F(1,177)=4.28, p<.05, d=.310$, on a $1-5$ scale $)$, and regular workshop meetings $(M=2.80[S D=1.30]$ vs $M=2.28[S D=1.35]$, $F(1,177)=6.80, p<.05 ; d=.392$, on a $1-5$ scale) preparing for parenting. There were no significant differences between people involved in a romantic relationship and singles in other aspects of the vision of own parenting. The single most surprising observation to emerge from the data comparison was that people engaged in a romantic relationship planned to have children later than singles $(M=27.71[S D=2.60]$ vs $M=26.8[S D=2.51], F(1,178)=4.01$, $p<.05, d=.356)$. This result will be discussed later in the study.

In regard to Hypothesis 2, assuming that cumulative time spent in a romantic relationship is correlated with higher extension and optimism of the vision of own parenting, results are generally similar. People who had spent more time in romantic relationships more often mentioned family life and specified a desired number of children in their answers related to predictions about their own life at the age of 35 . They also more often had reflections on the planned number of children and desired age to have the first child (see Table 1).

Table 1. Time Spent in Romantic Relationships and Family Planning

\begin{tabular}{lllll}
\hline \multicolumn{1}{c}{ Aspects of vision of own parenting } & \multicolumn{3}{c}{$\begin{array}{c}\text { Time spent in romantic } \\
\text { relationships (in months) }\end{array}$} & \multirow{2}{*}{$\chi^{2}(2,178)$} \\
\cline { 2 - 3 } & $0-12$ & $13-24$ & $>24$ & \\
\hline $\begin{array}{l}\text { Family life / having a child mentioned in } \\
\text { narration about own life at 35 }\end{array}$ & $76 \%$ & $86 \%$ & $92 \%$ & $7.29^{*}$ \\
$\begin{array}{l}\text { Desired number of children in narration } \\
\text { about own life at 35 }\end{array}$ & $32 \%$ & $45 \%$ & $56 \%$ & \multirow{2}{*}{$8.61^{*}$} \\
$\begin{array}{l}\text { Reflection on desired total number of children } \\
\text { Reflection on desired age to have the first child }\end{array}$ & $78 \%$ & $81 \%$ & $97 \%$ & $14.48^{* *}$ \\
\hline$* p<.05 . * * p<.01$. & $57 \%$ & $77 \%$ & $83 \%$ & $13.16^{* *}$ \\
\hline
\end{tabular}


Based on Tables 2 and 3 it can be observed that people with longer time spent in romantic relationships were also more eager to engage in child care and take part in various forms of preparation for parenting. Similarly to the results referring to Hypothesis 1, no differences related to the length of time spent in romantic relationship in predictions about the following aspects of the vision of own parenting were found: ways of spending time with children, shape of intimate relationship after childbirth, relations between parenting and other aspects of life, and involvement in child care.

Table 2. Time Spent in Romantic Relationships and Readiness for Child Care

\begin{tabular}{|c|c|c|c|c|c|c|c|c|c|}
\hline \multirow{3}{*}{$\begin{array}{l}\text { Predicted involvement } \\
\text { in child care activities }\end{array}$} & \multicolumn{6}{|c|}{ Time spent in romantic relationships (in months) } & \multirow{3}{*}{$F(2,177)$} & \multirow{3}{*}{$p$} & \multirow{3}{*}{$\eta^{2}$} \\
\hline & \multicolumn{2}{|c|}{$0-12$} & \multicolumn{2}{|c|}{$13-24$} & \multicolumn{2}{|c|}{$>24$} & & & \\
\hline & $M$ & $S D$ & $M$ & $S D$ & $M$ & $S D$ & & & \\
\hline Feeding & $61.15_{\mathrm{a}}$ & 40.39 & 67.48 & 35.15 & $77.17_{\mathrm{a}}$ & 33.91 & 3.55 & .031 & .039 \\
\hline Bathing & $88.63_{\mathrm{a}}$ & 16.52 & $79.07_{\mathrm{a}, \mathrm{b}}$ & 25.81 & $89.47_{\mathrm{b}}$ & 16.71 & 3.78 & .025 & .041 \\
\hline Changing diapers & 82.78 & 21.49 & $75.22_{\mathrm{b}}$ & 28.89 & $88.08_{b}$ & 17.75 & 4.07 & .019 & .044 \\
\hline
\end{tabular}

Note. Means in a row sharing subscripts significantly differ from each other. The scale is from 0 to 100 .

Table 3. Time Spent in Romantic Relationships and Readiness to Take Part in Activities Preparing for Parenting

\begin{tabular}{|c|c|c|c|c|c|c|c|c|c|}
\hline \multirow{3}{*}{ Preparation for parenting } & \multicolumn{6}{|c|}{$\begin{array}{l}\text { Time spent in romantic relationships } \\
\text { (in months) }\end{array}$} & \multirow{3}{*}{$F(2,176)$} & \multirow{3}{*}{$p$} & \multirow{3}{*}{$\eta^{2}$} \\
\hline & \multicolumn{2}{|c|}{$0-12$} & \multicolumn{2}{|c|}{$13-24$} & \multicolumn{2}{|c|}{$>24$} & & & \\
\hline & $M$ & $S D$ & $M$ & $S D$ & $M$ & $S D$ & & & \\
\hline $\begin{array}{l}\text { Academic lecture about } \\
\text { parenting }\end{array}$ & $2.80_{\mathrm{a}}$ & 1.27 & $2.65_{b}$ & 1.38 & $3.49_{\mathrm{a}, \mathrm{b}}$ & 1.18 & 7.82 & $<.001$ & 0.082 \\
\hline $\begin{array}{l}\text { Q\&A meeting with } \\
\text { experienced parents }\end{array}$ & 2.65 & 1.26 & $2.26_{b}$ & 1.32 & $3.13_{\mathrm{b}}$ & 1.26 & 5.90 & .003 & 0.063 \\
\hline $\begin{array}{l}\text { Individual consultation with } \\
\text { psychologist about preparation } \\
\text { for parenting }\end{array}$ & 3.00 & 1.40 & 2.65 & 1.22 & 3.25 & 1.32 & 2.30 & .104 & 0.025 \\
\hline Workshop about parenting & 2.58 & 1.36 & $2.23_{\mathrm{b}}$ & 1.15 & $3.03_{\mathrm{b}}$ & 1.36 & 4.62 & .011 & 0.050 \\
\hline $\begin{array}{l}\text { Regular group meetings } \\
\text { (lectures and workshops) } \\
\text { preparing for parenting }\end{array}$ & 2.49 & 1.39 & $2.03_{b}$ & 1.22 & $2.87_{b}$ & 1.28 & 4.70 & .010 & 0.051 \\
\hline
\end{tabular}

Note. Means in a row sharing subscripts significantly differ from each other. The scale is from 1 to 5. 


\section{STUDY 2}

\section{Method}

\section{Participants and Procedure}

Study 2 was carried out in a paper version (83\%) and online version $(17 \%){ }^{3}$ The groups did not differ in terms of their intimate relationship status $\left(\chi^{2}(1,412)\right.$ $=1.78, p=.620)$, but differed in terms of gender $\left(\chi^{2}(1,412)=38.70, p<.001\right.$; there were more women in the group of participants filling on-line version) and age $(t(408)=-3.44, p<.001$; mean age was higher in the group of participants filling on-line version). In total, 413 participants aged between 17 and 29 $(M=19.80, S D=2.57)$ were recruited in Study $2 ; 54.4 \%(n=224)$ of them were female, while $46.0 \%(n=188)$ were male. With regard to a romantic relationship, $53.4 \%(n=219)$ were single, $41.0 \%(n=167)$ were partnered, but not cohabiting, $3.9 \%(n=16)$ were involved, and $27.0 \%(n=8)$ were married. With respect to the declared socioeconomic status, $2.9 \%(n=12)$ declared a bad or a very bad SES, $46.9 \%(n=192)$ declared average SES, and $50.1 \%(n=204)$ declared SES "better than average." All the participants were native citizens of Poland. $31.6 \%(n=130)$ of them lived in a village, $33.8 \%(n=139)$ in a town, and $34.5 \%(n=142)$ in a city.

\section{Research Methods}

To measure the vision of own parenting, the Vision of Own Parenting Questionnaire (VOPQ; Janowicz et al., 2019) was used. The VOPQ includes 78 items divided into 10 scales: Parenthood planning [PL], Preparation-Knowledge $[\mathrm{P}-\mathrm{K}]$, Preparation-Maturity [P-M], Preparation-Conditions [P-C], Doubts [D], Parenthood Valuing [PV], Relationship with Intimate Partner [R], Upbringing Methods [UM], Influence on Child [I], and Ways of Spending Time with Child [ST]. The higher the result on each scale, the higher the level of extension of this particular component of the vision of own parenting (more aspects were included in the individual's personal vision of future parenting in relation to this specific

\footnotetext{
${ }^{3}$ Similarly to the results of Study 1, some differences between both groups were observed. Participants who filled the on-line version achieved higher scores in the following scales of the VOPQ: Preparation-Knowledge, Preparation-Maturity, Preparation-Conditions, Doubts, and Ways of Spending Time. In line with the findings of Study 1, those differences were more due to gender and age inequalities in both groups.
} 
component of the VOP). The VOPQ scales demonstrated a high internal consistency level (Cronbach's $\alpha$ from .73 to .89).

\section{Results}

Similarly to the part on Study 1, the results of Study 2 will be presented in the following manner. Firstly, results supporting and challenging Hypothesis 1 will be presented, followed by results supporting and challenging Hypothesis 2 . The analyses conducted in this study include: a t-test for independent samples, one-way analyses of variance (ANOVA, ANCOVA), and analyses of correlation (Pearson).

As shown in Table 4, also in Study 2, many differences in the level of extension of the vision of own parenting were observed between coupled people and singles. Effect sizes of the aforementioned differences were moderate. Being a parent in the future was more important for romantically involved people. They also have more extended VOP in the following aspects such as: parenthood planning, upbringing methods, influence on children, and ways of spending time with children; and predicted more positive changes in their romantic relationship after childbirth.

Table 4. Status of Romantic Relationship and Extension of Vision of Own Parenting

\begin{tabular}{|c|c|c|c|c|c|c|c|}
\hline \multirow{2}{*}{$\begin{array}{l}\text { Aspect of the vision } \\
\text { of own parenting }\end{array}$} & \multicolumn{2}{|c|}{ Single } & \multicolumn{2}{|c|}{ In relationship } & \multirow{2}{*}{$t(406)$} & \multirow{2}{*}{$p$} & \multirow{2}{*}{ Cohen's $c$} \\
\hline & $M$ & $S D$ & $M$ & $S D$ & & & \\
\hline Parenthood Planning (PL) & 18.52 & 5.99 & 21.86 & 6.67 & -5.32 & $<.001$ & -0.528 \\
\hline $\begin{array}{l}\text { Preparation-Knowledge } \\
(\mathrm{P}-\mathrm{K})\end{array}$ & 22.74 & 5.44 & 23.56 & 5.64 & 1.50 & .134 & -0.149 \\
\hline $\begin{array}{l}\text { Preparation-Maturity } \\
(\mathrm{P}-\mathrm{M})\end{array}$ & 27.53 & 5.67 & 28.30 & 5.23 & -1.41 & .159 & 1.140 \\
\hline $\begin{array}{l}\text { Preparation-Conditions } \\
(\mathrm{P}-\mathrm{C})\end{array}$ & 32.79 & 6.40 & 32.65 & 6.82 & 0.20 & .842 & 0.020 \\
\hline Doubts (D) & 40.39 & 8.71 & 38.86 & 8.78 & 1.76 & .079 & -0.412 \\
\hline Parenthood Valuing (PV) & 29.03 & 8.73 & 32.75 & 9.34 & -4.15 & $<.001$ & -0.041 \\
\hline $\begin{array}{l}\text { Relationships with } \\
\text { Intimate Partner (R) }\end{array}$ & 32.85 & 7.05 & 36.56 & 6.87 & -5.36 & $<.001$ & -0.532 \\
\hline Upbringing Methods (UM) & 48.92 & 7.78 & 51.33 & 7.17 & -3.22 & .001 & -0.321 \\
\hline Influence on Child (I) & 32.52 & 4.89 & 34.01 & 4.46 & -3.19 & .002 & -0.317 \\
\hline Ways of Spending Time (ST) & 36.81 & 7.15 & 39.67 & 5.75 & -4.40 & $<.001$ & -0.437 \\
\hline
\end{tabular}


It can be seen on the basis of the data in Table 5 that people with longer cumulative time spent in romantic relationships had more extended vision of own parenting in the following aspects: parenthood planning, gaining knowledge as preparation for parenting, and ways of spending time with a child. They also had fewer doubts about being a parent in the future and predicted more positive changes in their romantic relationship after childbirth. Being a parent in the future in itself was also more important for people who spent more time in romantic relationships.

Table 5. Time Spent in Romantic Relationships and Extension of Vision of Own Parenting

\begin{tabular}{|c|c|c|c|c|c|c|c|c|c|}
\hline \multirow{3}{*}{$\begin{array}{l}\text { Aspect of vision } \\
\text { of own parenting }\end{array}$} & \multicolumn{6}{|c|}{ Time spent in romantic relationships (in months) } & \multirow{3}{*}{$F(2,407)$} & \multirow{3}{*}{$p$} & \multirow{3}{*}{$\eta^{2}$} \\
\hline & \multicolumn{2}{|c|}{$0-12$} & \multicolumn{2}{|c|}{$13-24$} & \multicolumn{2}{|c|}{$>24$} & & & \\
\hline & $M$ & $S D$ & $M$ & $S D$ & $M$ & $S D$ & & & \\
\hline $\begin{array}{l}\text { Parenthood } \\
\text { Planning (PL) }\end{array}$ & $18.72_{\mathrm{a}, \mathrm{b}}$ & 6.12 & $21.22_{\mathrm{a}}$ & 6.37 & $21.56_{\mathrm{b}}$ & 6.82 & 9.40 & $<.001$ & 0.044 \\
\hline $\begin{array}{l}\text { Preparation- } \\
\text { Knowledge (P-K) }\end{array}$ & 22.65 & 5.69 & 24.32 & 4.94 & 23.29 & 5.53 & 2.45 & .088 & 0.012 \\
\hline $\begin{array}{l}\text { Preparation- } \\
\text { Maturity (P-M) }\end{array}$ & 27.66 & 5.73 & 29.26 & 5.00 & 27.59 & 5.26 & 2.57 & .078 & 0.012 \\
\hline $\begin{array}{l}\text { Preparation- } \\
\text { Conditions (P-C) }\end{array}$ & 33.06 & 6.56 & 33.70 & 5.92 & 31.70 & 6.85 & 2.66 & .072 & 0.013 \\
\hline Doubts (D) & 40.52 & 9.13 & 40.25 & 8.14 & 38.26 & 8.50 & 2.83 & .060 & 0.014 \\
\hline $\begin{array}{l}\text { Parenthood } \\
\text { Valuing (PV) }\end{array}$ & $28.67_{a, b}$ & 8.69 & $32.64 \mathrm{a}$ & 8.64 & $33.02_{b}$ & 9.50 & 11.39 & $<.001$ & 0.053 \\
\hline $\begin{array}{l}\text { Relationship with } \\
\text { Intimate Partner (R) }\end{array}$ & $33.48_{a, b}$ & 7.47 & $36.09_{\mathrm{a}}$ & 7.05 & $35.46_{b}$ & 6.56 & 5.04 & .007 & 0.024 \\
\hline $\begin{array}{l}\text { Upbringings } \\
\text { Methods (UM) }\end{array}$ & $49.00_{\mathrm{a}}$ & 8.27 & $51.58_{\mathrm{a}}$ & 6.87 & 50.80 & 6.54 & 4.08 & .018 & 0.020 \\
\hline $\begin{array}{l}\text { Influence } \\
\text { on a Child (I) }\end{array}$ & $32.55_{a}$ & 5.02 & $34.15_{\mathrm{a}}$ & 4.82 & 33.81 & 4.13 & 4.46 & .012 & 0.021 \\
\hline $\begin{array}{l}\text { Ways of Spending } \\
\text { Time (ST) }\end{array}$ & $36.82_{a, b}$ & 7.26 & $39.25_{\mathrm{a}}$ & 5.61 & $39.55_{\mathrm{b}}$ & 5.83 & 8.22 & $<.001$ & 0.039 \\
\hline
\end{tabular}

Note. Means in a row sharing subscripts significantly differ from each other.

A one-way ANCOVA was conducted to determine a statistically significant difference between singles, and coupled people on vision of own parenting controlling for gender. There was no significant effect of interaction between the intimate relationship status and gender in relation to any of the vision of own parenting aspects. 
The last set of analyses revealed that extension of the vision of own parenting was slightly positively correlated with total time spent in intimate relationships in the following aspects: parenthood planning $(r=.20, p<.001)$, upbringing methods ( $r=.14, p<.01)$, influence on a child's life $(r=.12, p<.01)$, and ways of spending time $(r=.20, p<.001)$. People who spent a longer time in intimate relationships also predicted more positive changes in their relationship after childbirth $(r=.11, p<.05)$ and attached a greater value to being a parent in the future $(r=.19, p<.001)$. The only aspect of the VOP negatively correlated with the total time spent in intimate relationships was the preparation conditions $(r=-.15, p<.01)$.

\section{GENERAL DISCUSSION}

These studies were designed to examine differences in the content and the structure of the vision of own parenting in people involved in a romantic relationship and singles. This project was also undertaken to verify if and how a longer time spent in romantic relationships is related to the development of the vision of own parenting. The posed hypotheses have been partially confirmed.

The studies have shown that coupled people have a generally more extensive vision of own parenting than singles, but only in relation to the chosen aspects of the VOP. The second major finding of the present studies was that these differences were bigger in the aspects of the VOP related to the parenthood planning, preparation for parenting, and parenthood valuing. Thirdly, it can be said referring to these data, that people with longer cumulative time spent in romantic relationships have more extended VOP than people, who have less experience of being in romantic relationships. These results in part bridge the gap in current knowledge on the role of being involved in an intimate relationship in forming predictions about own future in relation to parenting. The findings of both studies partially support the thoughts of many authors (e.g., Crissey, 2005; Joyner \& Udryn, 2000; Schulman \& Seiffge-Krenke, 2001) who claim that experience gained in romantic relationships is related to preparation for parenting and attitudes toward it. These results will be discussed in relation to other studies on the vision of own parenting and some theoretical concepts.

Sternberg (1986, as cited in Wojciszke, 2015) claims that intimacy develops at the subsequent stages of the romantic relationship (especially in its first few years). Developing intimacy is related to growing trust and mutual dependence (also in terms of developing common life plans). Subjects related to future family life may be present in discussions of the partners. Growing intimacy in this 
relationship may support forming the Dream and living it out, also in relation to parenthood (Levinson, 1988). The role of characteristic of relation between partners for shaping their plans and predictions about future may be also concluded from Havighurst's thoughts (1981, pp. 85-89), but he describes the order of realising developmental goals in early adulthood. Selecting a mate and learning to live with a marriage partner precede starting a family. It is therefore likely that effects of that "learning" may influence partners' plans and predictions related to being parents in the future. What is more, sharing personal thoughts and emotions related to that topic with an intimate partner may lead partners being better prepared (as a couple) for pregnancy, childbirth, and parenting (Kuryś, 2010). Interestingly, Levinson (1988) highlighted that partners' agreement in worldview and attitudes toward traditional and modern patterns of family life may influence the process of forming the Dream. It is possible to hypothesise that partners with more similar worldview, life values and attitudes toward family roles will have more similar vision of own parenting, which should lead to fewer problems during transition to parenthood (Fleming et al., 1988). Longitudinal studies involving both partners are needed to verify it.

The observed fact that being a parent in the future is more important for people involved in a romantic relationship than for singles may indicate that developing this relationship, and the effort put in it, may be considered by the partners as preparation for starting a family. It was described in this light by Havighurst in his theory (1981) and mentioned by Skowroński in his paper (2011) about sexual development in relation to developmental tasks in early adulthood. The aforementioned results revealing that coupled people prefer to have children later than singles may be better understood in this context. A possible explanation for this might be that parenthood is more important for coupled people, so they want to be better prepared for it. This explanation with the findings of Liberska (2004), who found that in the group of young people taking part in her research more important expectations were located in a more distant temporal perspective. This result may be also explained by the fact that having a baby may be considered as a threat for a satisfying romantic relationship, which may lead to postponing starting a family. This explanation is consistent with findings of studies on voluntary childlessness (Cieślińska, 2014; Garncarek, 2017; Wacławik, 2012). However, other results of the presented research ${ }^{4}$ lead to the conclusion that this

\footnotetext{
${ }^{4}$ No significant correlations $(r=.13 ; p=.08)$ in Study 1 and weak negative correlation $(r=-.17, p<.01)$ in Study 2 were observed between parenthood valuing and number of conditions perceived as necessary to start a family; in the entire sample (in Study 1) higher parenthood valuing was positively correlated with the will to have a baby earlier $(r=.295 ; p<.01)$.
} 
specific result is rather related to the structure of the research sample. Being in a romantic relationship was more often reported by young adults, whose temporal perspective of their life plans tends to be more extended in time (Liberska, 2004). These results reveal a wealth of factors influencing procreation plans in young people.

The results of Study 1 show that being in a romantic relationship is to a greater extent related to a more extended vision of own parenting in men than in women. The results of Study 2 are not in line with it. Wojciszke (2002) and Przybył (2001) pointed out that the process of boys' socialization, contrary to socialization of girls, is less focused on preparation for fulfilling family roles. This suggests that experience gained in romantic relationships may, somehow, compensate earlier shortages in the process of socialization and lead to development of the vision of own parenting. Further studies should be done to verify if being (or not) in a romantic relationship may play a different role in the process of development of the VOP among men and women.

Surprisingly, no difference in the extension of many aspects of the vision of own parenting (especially in Study 1) between coupled people and singles was observed. There are several possible explanations for this outcome. First, it is possible that status of an intimate relationship should be taken into consideration. It may be predicted that romantically involved or married people will have greater expectations about their future family life than dating people. However, in this study it was impossible to verify this in a proper way because of a limited number of romantically involved and married participants. Further research, which would include a higher number of both, needs to be conducted. Second, the observed results could be attributed to "natural" dynamic of the process of the VOP development. It is possible to hypothesise that some general reflection on that matter (family planning, ways of spending time with a child) develops firstly and then more specific thoughts (e.g., especially related to preparation for parenting) develop. To verify this hypothesis longitudinal studies should be conducted. Finally, findings from studies on the process of transition to parenthood (Kuryś, 2010; Way, 2012) suggest that experience of young parents related to first months after childbirth were largely inconsistent with earlier predictions about this period of their life. It may be possible that this subject is too abstract and distant for teenagers and young adults. An implication of acceptance of this thesis will be the necessity of looking for another factors related to development of the vision of own parentingthan being (or not) engaged in a romantic relationship —e.g., future orientation and life values (Janowicz et. al., 2019). 


\section{LIMITATIONS}

The findings in this report are subject to a few more limitations than those previously mentioned in this paper. First, with respect to sample characteristic, findings can be only partially generalized onto a different group (e.g., people living in towns and villages). Second, the inability to assess qualitative data by a bigger group of judges indicates caution in the extension of conclusions based on these data. Thirdly, as it was mentioned, the results in both studies were slightly different in the group filling the paper version and the group filling the on-line version. However, those differences were rather related to the fact that both groups differed in terms of gender, age, and status of an intimate relationship. Nevertheless, the manner of data gathering should be taken into consideration during planning further studies on that topic, as a possible factor influencing the results. Finally, results in both studies were somehow inconsistent, which may be related to the method of measurement (qualitative or quantitative) and the manner of gathering data (paper vs on-line versions) (Janowicz, in press). Further studies should be done to assess that.

\section{CONCLUSIONS}

The findings of the presented research show that the status of an intimate relationship and experience gained in it are related to the content and the structure of the vision of own parenting. However, observed differences were not very big and they were revealed only in relation to a few aspects of the vision of own parenting. These findings and the aforementioned limitations of the research reveal what is now needed to be done in this subject. First, conducting longitudinal studies on the process of the development of the vision of own parenting in singles and coupled people should be conducted. Second, it would be interesting to examine this process in the succeeding stages of the romantic relationship (dating, engagement, marriage). Another possible area of further research would be to investigate the cohesion of the VOP between romantic partners. In relation to this topic it might be fruitful to consider Murray Bowen's (2004) theory and his concept of the differentiation of the self. Especially aspects related to the fusion with partner and dependency on the partner (Babiuch \& Kriegelewicz, 2002, as cited in Kucharska \& Janicka, 2018) may be important in this context (Kriegelewicz, 2010). Further longitudinal research might indicate if and how 
this cohesion develops at further stages of the relationship, and if and how it is adaptive in the process of transition to parenthood.

Information from this study can be used to develop targeted interventions (e.g., classes or workshops) aimed at supporting teenagers and young adults in preparation for parenting. Findings revealing a rather low or moderate level of VOP extension in teenagers, whether single or with a boyfriend/girlfriend, indicate the necessity of interventions aimed at developing future orientation and prospective motivation before engaging them in classes directly intended to prepare for parenthood. The results of the presented research indicate also a considerable need for supporting even coupled people preparing for marriage and family life (e.g., in church or antenatal classes) in building their own self-image as future parents. Interventions considering knowledge gained in this research may support young people in the process of transition to parenthood and decrease the risk of psychological problems in this stage of their life.

\section{REFERENCES}

Babiuch, M. E., \& Kriegelewicz, O. (2002, September 5-8). Zależność od współmałżonka a satysfakcja małżeńska [Dependency on the spouse and marital satisfaction]. Paper presented at the 31st Scientific Congress of Polish Psychological Association, Lublin, Poland.

Bakiera, L. (2009). Czy dorastanie musi być trudne? [Does growing up have to be difficult?]. Scholar.

Beisert, M. (2012). Trud dorastania seksualnego [Hardships of sexual growing up]. In M. Beisert (Ed.), Seksualność w cyklu życia człowieka [Sexuality in the human's life cycle] (pp. 145169). PWN.

Bloom, D. E., \& Pebley, A. R. (1982). Voluntary childlessness: A review of the evidence and implications. Population research and policy review, 1(3), 203-224.

Braithwaite, S. R., Delevi, R., \& Fincham, F. D. (2010). Romantic relationships and the physical and mental health of college students. Personal relationships, 17(1), 1-12.

Bowen, M. (2004). Family therapy in clinical practice. Jason Anderson.

Cieślińska, B. (2014). Bezdzietność jako styl życia [Childlessness as a lifestyle]. Pogranicze. Studia Spoteczne, 24, 277-292.

Crissey, S. R. (2005). Race/ethnic differences in the marital expectations of adolescents: The role of romantic relationships. Journal of Marriage and Family, 67(3), 697-709.

Cross-Barnet, C., Cherlin, A., \& Burton, L. (2011). Bound by children: Intermittent cohabitation and living together apart. Family Relations, 60, 633-647.

Dziwańska, K. (2007). Cele i plany życiowe młodzieży a rozwój perspektywy przyszłościowej - wyniki badań [Life goals and life plans and development of the future time perspectiveresearch report]. Psychologia Rozwojowa, 12(4), 75-84.

Erikson, E. H. (1997). Dzieciństwo i spoteczeństwo [Childhood and society]. Rebis.

Erikson, E. H. (2004). Tożsamość a cykl życia [Identity and the life cycle]. Zysk i S-ka. 
Gajtkowska, M. (2016). Rola matki jako obszar dylematów współczesnych kobiet. Badania własne [Dilemmas of contemporary women related to their maternal role. Research report]. Retrieved July 6, 2017, from http://www.repozytorium.ukw.edu.pl/bitstream/handle/item/3696/Mag dalena\%20Gajtkowska\%20Rola\%20matki\%20jako\%20obszar\%20dylematow\%20wspolczes nych $\% 20$ kobiet $\% 20$ Badania $\% 20$ wlasne.pdf? sequence $=1$

Garncarek, E. (2017). Podejmowanie decyzji o dobrowolnej bezdzietności w kontekście jakości relacji małżeńskiej [Taking a decision about voluntary childlessness in the context of marital relationship quality]. Dyskursy młodych andragogów, 18, 373-387.

Goodwin, J. S., Hunt, W. C., Key, C. R., \& Samet, J. M. (1987). The effect of marital status on stage, treatment, and survival of cancer patients. Jama, 258(21), 3125-3130.

Havighurst, R. J. (1981). Developmental tasks and education. Longman.

Izdebski, Z. (2012). Seksualność Polaków na początku XXI wieku. Studium badawcze [Sexuality of Poles in the early 21 st century. Empirical study]. Wydawnictwo Uniwersytetu Jagiellon'skiego.

Jacques, H. A. K., \& Radtke, H. L. (2012). Constrained by choice: Young women negotiate the discourse of marriage and motherhood. Feminism \& Psychology, 22(4), 443-461.

Janicka, I. (2012). Poczucie dobrostanu u osób poślubionych, kohabitujących i singli [Well-being in spouses, cohabitants and singles]. In T. Rostowska \& A. Lewandowska-Walter (Eds.), Matżeństwo $i$ rodzicielstwo a zdrowie [Marriage, parenthood and health] (pp. 26-53). Wydawnictwo Adam Marszałek.

Janowicz, K. (2017). Wizja własnego ojcostwa u mężczyzn w późnej adolescencji $i$ wczesnej dorostości. [The vision of own fatherhood in men in late adolescence and early adulthood] (Unpublished Master Thesis). Adam Mickiewicz University, Poznań, Poland.

Janowicz, K. (2018). Wizja własnego ojcostwa u mężczyzn w późnej adolescencji [The vision of own fatherhood in men in late adolescence]. Zeszyty Naukowe Towarzystwa Doktorantów UJ. Nauki Społeczne, 22(3), 149-181.

Janowicz, K., \& Bakiera, L. (2018). Levinsonowskie Marzenie w odniesieniu do ojcostwa. Badanie studentów w fazie nowicjatu [The Levinsonian Dream in relation to fatherhood. Research on students in the novice phase]. Psychologia Rozwojowa, 23(4), 71-90.

Janowicz, K. (in press). Zagadnienia metodologiczne związane z pomiarem wizji własnego rodzicielstwa [Metodological issuess related to the assessment of the vision of own parenting]. In L. Bakiera (Ed.), Rodzicielstwo. Ujęcie interdyscyplinarne [Parenting. An interdisciplinary view]. Wydawnictwo Naukowe UAM.

Janowicz, K., Ciesielski, P., \& Górska, M. (2019, March 14-15). Konstrukcja i walidacja Kwestionariusza Wizji Własnego Rodzicielstwa [Development and Validation of the Vision of Own Parenting Questionnaire]. Paper presented at the 4th Psychometric Meetings in Katowice. University of Silesia, Katowice, Poland.

Joyner, K., \& Udry, J. R. (2000). You don't bring me anything but down: Adolescent romance and depression. Journal of Health and Social Behavior, 41, 369-391.

Kucharska, M., \& Janicka, I. (2018). Zależność i wsparcie od partnera a więź matki z dzieckiem w okresie prenatalnym [Dependence on intimate partner, social support and maternal-fetal attachment]. Polskie Forum Psychologiczne, 23(1), 139-156.

Kuryś, K. (2010). Urodzenie pierwszego dziecka jako wydarzenie krytyczne $w$ życiu kobiet $i$ mężczyzn [The first child birth as a critical life event in men's and women's life]. Impuls.

Kriegelewicz, O. (2010). Kwestionariusz Relacji do pomiaru stopnia zróżnicowania Ja konstrukcja i analiza właściwości psychometrycznych [Relation Questionnaire for the assess- 
ment of the Self differentiation: Development and Validation]. Przeglad Psychologiczny, 53(4), 417-437.

Lampic, C., Svanberg, A. S., Karlstrom, P. O., \& Tyden, T. (2006). Fertility awareness, intentions concerning childbearing, and attitudes towards parenthood among female and male academics. Human Reproduction, 21(2), 558-564.

Levinson, D. J. (1988). The seasons of a man's life. Alfred A. Knopf.

Liberska, H. (2004). Perspektywy temporalne młodzieży. Wybrane uwarunkowania [Teenagers' temporal perspectives. Selected conditions]. Wydawnictwo Naukowe UAM.

Maher, J. M., Dever, M., Curtin J., \& Singleton A. (2004). What women (and men) want: Births, policies and choices. School of Political and Social Inquiry.

Majdzińska, A., \& Śmigielski, W. (2010). Wizja własnej przyszłości zawodowej i rodzinnej studentów Uniwersytetu Lódzkiego [The vision of own family and occupational future in students of the University of Lodz]. In M. Chromińska \& I. Kuropka (Eds.), Spoleczne $i$ ekonomiczne konsekwencje zmian procesów demograficznych [Social and economical consequences of demographic processess] (pp. 25-42). Sekcja Analiz Demograficznych, Polish Academy of Sciences.

Majorczyk, M. (2014). Ojcostwo jako zadanie rozwojowe w życiu mężczyzny. Komunikat z badań [Fatherhood as a developmental task in a man's life. Research report]. In B. Raszeja-Kotleba \& M. Baranowska-Szczepańska (Eds.), On bez tajemnic. Problemy, analizy, perspektywy [The "He" exposed. Problems, analyses, perspectives] (pp. 41-58). Instytut NaukowoWydawniczy Maiuscula.

Marsiglio, W., Hutchinson, S., \& Cohan, M. (2000). Envisioning fatherhood: A social psychological perspective on young men without kids. Family Relations, 49, 133-142.

Murphy, M., Glaser, K., \& Grundy, E. (1997). Marital status and long-term illness in Great Britain. Journal of Marriage and the Family, 59(1), 156-164.

Ostoja-Zawadzka, K. (1999). Cykl życia rodzinnego [The cycle of a family life]. In B. de Barbaro (Ed.), Wprowadzenie do systemowego rozumienia rodziny [An introduction to the systemic psychology of the family] (pp. 18-30). Wydawnictwo Uniwersytetu Jagiellońskiego.

Przybył, I. (2001). Źródła wiedzy o rolach małżeńskich [Sources of knowledge about marital roles]. Roczniki Socjologii Rodziny, 13, 105-116.

Fleming, A. S., Ruble, D. N., Flett, G. L., \& Shaul, D. L. (1988). Postpartum adjustment in firsttime mothers: Relations between mood, maternal attitudes, and mother-infant interactions. Developmental psychology, 24(1), 71.

Shulman, S., \& Seiffge-Krenke, I. (2001). Adolescent romance: Between experience and relationships. Journal of Adolescence, 24, 417-428.

Skoog Svanberg, A., Lampic, C., Karlstrom, P. O., \& Tyden, T. (2006). Attitudes toward parenthood and awareness of fertility among postgraduate students in Sweden. Gender Medicine, 3(3), 187-195.

Skowroński, D. (2011). Psychologia rozwoju człowieka dorosłego [Psychology of adult development]. Retrieved May 16, 2017, from http://poradnictwo-psychologiczne.p1/2011/03/ psychologia-rozwoju-czlowieka-doroslego

Smith, J. L., Fenwick, J., Skinner, R., Merriman, G., \& Hallet, J. (2011). Young males' perspectives on pregnancy, fatherhood and condom use: Where does responsibility for birth control lie? Sexual \& Reproductive Healthcare, 2(1), 37-42.

Tanturri, M. L., \& Mencarini, L. (2008). Childless or childfree? Paths to voluntary childlessness in Italy. Population and development review, 34(1), 51-77. 
Thompson, R., Lee, Ch., \& Adams, J. (2013). Imagining Fatherhood: Young Australian men's perspectives on fathering. International Journal of Mens' Health, 12(2), 150-165.

Twenge, J. M., Campbell, W. K., \& Freeman, E. C. (2012). Generational differences in young adults' life goals, concern for others, and civic orientation. Journal of personality and social psychology, 102(5), 1966-2009.

Virtala, A., Vilska, S., Huttunen, T., \& Kunttu, K. (2001). Childbearing, the desire to have children, and awareness about the impact of age on female fertility among Finnish university students. The European Journal of Contraception and Reproductive Health Care, 16(2), 108-115.

Wacławik, S. (2012). W stronę społeczeństwa bez dzieci [Heading towards the society without children]. Palimpsest. Czasopismo Socjologiczne, 2, 22-37.

Way, S. (2012). A qualitative study exploring women's personal experiences of their perineum after childbirth: expectations, reality and returning to normality. Midwifery, 28(5), 712-719.

Wojciszke, B. (2002). Kobiety i mężczyźni: odmienne spojrzenie na różnice [Women and men: A diverse look at the differences]. Gdańskie Wydawnictwo Psychologiczne. 